\title{
Incidence of antibiotic resistant pathogenic bacteria in vegetable items sold by local and super shops in Dhaka city
}

\author{
Ahmed Kabir, Ashish Kumar Das and Md. Shahidul Kabir \\ Department of Microbiology, Stamford University Bangladesh, 51 Siddeswari Road, Dhaka 1217, \\ Bangladesh
}

Received 20 May 2014/Accepted 25 July 2014

\begin{abstract}
The present study was carried out to investigate the microbiological quality and antibiotic resistance patterns of pathogenic bacteria isolated from vegetable samples. A total of 14 vegetable samples, 7 from local and 7 from super shops, were randomly collected from different locations of Dhaka city. Concentrations of total heterotrophic bacteria, total coliform, faecal coliform, Pseudomonas spp., Listeria spp. and Staphylococcus aureus were enumerated from each sample by serial dilution and spread plate technique. Presence of Salmonella spp., Shigella spp. and Vibrio spp. were determined by enrichment and selective plating methods. Antibiotic sensitivity patterns of the isolated bacteria were determined using Imipenem (10 $\mu \mathrm{g})$, Ceftriaxone (30 $\mu \mathrm{g})$, Sulphamethoxazole (25 $\mu \mathrm{g})$, Ampicillin (10 $\mu \mathrm{g})$, Gentamicin $(10 \mu \mathrm{g})$, Aztreonam $(30 \mu \mathrm{g})$, Cefuroxime $(30 \mu \mathrm{g})$ and Oxacillin $(5 \mu \mathrm{g})$ antibiotic discs. The local market vegetables showed higher proportions of $E$. coli $(4 / 7,57.14 \%)$ but the super shop vegetables showed higher proportions of Pseudomonas spp. (5/7, 71.42\%) and Listeria spp. (5/7, $\mathbf{7 1 . 4 2 \%}$ ). Pathogenic bacteria isolated form the super shops showed increased resistance against (5/8, $62.5 \%$ ) antibiotics tested against the pathogenic bacteria. Contamination of vegetables by a range of pathogenic bacteria in local and super market vegetables is a serious threat to public health if they are consumed raw or unprocessed. Higher antibiotic resistance in pathogens isolated form supermarket vegetables needs to be investigated in order to monitor and control spread of infections with drug resistant bacteria.
\end{abstract}

Key words: Vegetables; Contamination; Microbiological quality; Antibiotic resistance

Vegetables constitute a major part of our daily meal and meet the requirements of nutrients, vitamin and minerals. Although vegetables generally contain a load of $10^{3}$ to $10^{5}$ microorganisms $/ \mathrm{cm}^{3}$ or $10^{4}$ to $10^{7}$ microorganisms/g, they may harbor a number of pathogenic microorganisms dispersed over the plants or micro colonies in the plant tissues (1). The predominant bacterial types found on vegetables are lactic acid bacteria, Corynebacterium, Enterobacter, Proteus, Micrococcus, Enterocoocus, Pseudomonas and sporeformers. They may also possess different types of molds, such as Alternaria, Fusarium, and Aspergillus growing on their surface. Vegetables can be contaminated by enteric pathogens if animal or human wastes and polluted water are used for fertilization and irrigation $(2,3)$. Raw vegetables may be bruised during processing and distribution resulting in the release of plant nutrients which may serve as the essential organic and inorganic substrates for microorganisms $(2,4)$. Variety of microorganisms including pathogens can be

†Corresponding Author: Mailing address. Dr. Md. Shahidul Kabir, Department of Microbiology, Stamford University Bangladesh, 51 Siddeswari Road, Dhaka 1217, Bangladesh; E-mail: mskabir@yahoo.com. introduced from the surface of vegetables during processing of fresh salad vegetables. A large number of pathogenic microorganisms including Salmonella, Escherichia coli O157:H7, Bacillus anthracis, Mycobacterium spp., Brucella spp., Listeria monocytogenes, Yersinia enterolytica, Clostridium perfringens, Klebsiella spp. and Mycobacterium paratuberculosis have been reported to be associated with contamination of vegetables. A number of bacterial diseases such as, diarrhoea, anthrax, salmonellosis, listeriosis, Crohn's disease and arthritis have been reported to be caused through consumption of contaminated vegetables by pathogenic microorganisms (5-8).

Vegetables can be contaminated from different environmental sources, such as soil, water, insects, air, birds, animal or equipment during cultivation and marketing. Pathogens present in contaminated foods may harbour virulence genes, toxins and enzymes, which aids in pathogenesis of infectious diseases $(9,10)$. In Bangladesh, food borne enteric disease is responsible for one third of childhood deaths each year from diarrhoeal diseases (11). Inception of supermarket for selling variety 
of food, vegetables and grocery items is new in the context of Bangladesh. There are few reports on different types of vegetables sold by the local and super markets. This study was therefore, conducted to determine the microbiological contamination of vegetable items sold by different outlets of local and super shops in Dhaka city.

\section{MATERIALS AND METHODS}

Sampling sites. Seven vegetable samples (Tomato, Cauliflower, Cabbage, Bean, Carrot, Radish, and Turnip) were aseptically collected from each of 7 local- and super-markets in Dhaka city. Samples were collected early in the morning in a sterile plastic bag and transported to the laboratory as soon as possible for further processing. This study was conducted between 1st February, 2014 and 15 April 2014.

TABLE 1. Description of the sites from where vegetable samples were collected

\begin{tabular}{cccc}
\hline $\begin{array}{c}\text { Sample } \\
\text { ID }\end{array}$ & $\begin{array}{c}\text { Sample } \\
\text { type }\end{array}$ & $\begin{array}{c}\text { Category } \\
\text { of shop }\end{array}$ & Location of market \\
\hline 1-T-L & Tomato & $\mathrm{L}$ & Bonani bazar \\
2-T-S & Tomato & $\mathrm{S}$ & Swapno, Mirpur \\
3-CF-L & Cauliflower & $\mathrm{L}$ & Kawran bazar \\
4-CF-S & Cauliflower & $\mathrm{S}$ & Swapno, shawrapara \\
5-CB-L & Cabbage & $\mathrm{L}$ & Mirpur 6 bazar \\
6-CB-S & Cabbage & $\mathrm{S}$ & Meena bazar, Mohammedpur \\
7-B-L & Bean & $\mathrm{L}$ & Mohakhali bazar \\
8-B-S. & Bean & $\mathrm{S}$ & Agora, Shanti nagar \\
9-CA-L & Carrot & $\mathrm{L}$ & Malibag bazar \\
10-CA-S & Carrot & $\mathrm{S}$ & Agora, Mog bazar \\
11-R-L & Radish & $\mathrm{L}$ & West Raza bazar \\
12-R-S & Radish & $\mathrm{S}$ & Agora, Dhanmondi \\
13-T-L & Turnip & $\mathrm{L}$ & Mirpur 11, Kacha bazar \\
14-T-S & Turnip & $\mathrm{S}$ & Meena bazar, Azimpur \\
\hline
\end{tabular}

$\mathrm{L}=$ Local market; $\mathrm{S}=$ Super market

Sample processing. All samples were processed following standard methods (12). $10 \mathrm{gm}$ of vegetable samples were weighted and added into $90 \mathrm{ml}$ of sterile normal saline in a blender and homogenized for 1-2 minutes before dilution and plating on both non-selective and selective media.

Inoculation and incubation of media. Samples were diluted up to $10^{-7}$ dilution following a 10-fold serial dilution technique and were spread on Nutrient Agar (NA) medium, Pseudomonas Agar (PA), Membrane Fecal Coliform (mFC) agar, Manitol Salt Agar (MSA) and Listeria Identification Agar (LIA) to determine total heterotrophic bacteria, Pseudomonas spp., total/faecal coliforms, Staphylococcus aureus and Listeria spp. respectively. All plates showing 30-300 colonies were used for quantitation of bacterial load as $\mathrm{cfu} / \mathrm{g}$ (13). All media were purchased in dehydrated powder form from Himedia Laboratories Ltd., India.

Heterotrophic bacterial count. Samples were serially diluted up to $10^{-7}$ and $0.1 \mathrm{ml}$ suspension of sample was inoculated on nutrient agar medium by using spread plate method for heterotrophic count of microbes. Then the plates were incubated at $37{ }^{\circ} \mathrm{C}$ for 24 hours. Any visible colonies were counted for determining the concentration of total heterotrophic bacteria.

Total coliform and faecal coliform count. $0.1 \mathrm{ml}$ of the diluted samples were spread on mFC agar and incubated at $37{ }^{\circ} \mathrm{C}$ and $44{ }^{\circ} \mathrm{C}$ for 24 hours for total coliform and faecal coliforms, respectively. After incubation characteristic blue colonies were counted to determine the concentration of total and faecal coliform.

Pseudomonas count on Pseudomonas agar. To enumerate the concentration of Pseudomonas spp., $0.1 \mathrm{ml}$ suspession from each sample was spread on the surface of the Pseudomonas agar medium and was incubated at $37{ }^{\circ} \mathrm{C}$ for 24 hours. After incubation, the bluish green colonies were counted as total Pseudomonas spp.

Enumeration of load of Staphylococcus aureus and Listeria spp. To enumerate the concentration of Staphylococcus aureus and Listeria spp., $0.1 \mathrm{ml}$ of suspension was spread onto MSA and LIA. Yellow colony with yellow halo were determined as Staphylococcus aureus and grey-green colonies black centre and a black halo were considered positive for Listeria spp.

Enrichment and isolation of Shigella spp., Salmonella spp. and Vibrio spp. Selenite Cystine broth and Alkaline Peptone water were used for enrichment of Salmonella/Shigella spp. and Vibrio spp. Following enrichment 2-3 loop of enriched media were streaked on selective plates for isolation of pathogenic bacteria (12). Plates were incubated at $37{ }^{\circ} \mathrm{C}$ for 24 hours. Transparent or transparent with black centred colonies on SS agar were suspected colonies of Shigella/Salmonella spp. Sucrose fermenting or non-fermenting colonies were considered as suspected colonies of Vibrio spp.

Biochemical tests for identification of pathogenic bacteria. A series of biochemical tests such as, KIA, MIU, citrate, catalase, oxidase, MR and VP tests were done for identification of the suspected pathogenic bacteria $(13,14)$.

Antibiotic susceptibility test. Inoculum was prepared from a discrete colony in Trypticase Soya Broth (TSB). Bacterial cell suspension was prepared to match the concentration of inoculum to that of $0.5 \mathrm{McFarland}$ standard. Bacterial suspension was inoculated on Mueller Hinton Agar (MHA) medium using sterile swab stick. Plates were dried for 15 minutes and commercially available antibiotic discs were applied on the plate surface. Imipenm (IPM) 10 $\mu$ g, Ceftriaxone (CRO) $30 \mu \mathrm{g}$, Sulfamethoxazole (SXT) $25 \mu \mathrm{g}$, Ampicillin (AMP) $10 \mu \mathrm{g}$, Genicintam (CN) 10 $\mu \mathrm{g}$, Aztronam (ATM) $30 \mu \mathrm{g}$, Cefuroxime (CXM) 30 $\mathrm{g}$ and Oxacillin (OX) $5 \mu \mathrm{g}$ discs from Himedia Laboratories Ltd., India were used to determine the sensitivity of the isolated bacteria. The plate was inverted incubated aerobically at $37^{\circ} \mathrm{C}$ for 24 hours. Sensitivity of the isolated bacteria was determined according to the Clinical and Laboratory Standards Institute guideline (15)

\section{RESULTS}

Total bacterial load in all samples tested from local and super markets are shown in Table 2. Count of total heterotrophic bacterial (THB) ranged between $3.5 \times 10^{4}$ and $7.4 \times 10^{5} \mathrm{cfu} / \mathrm{g}$ in all samples. Total coliforms (TC) were absent in $3(21.4 \%)$ samples out of 14 samples tested. None of the samples showed the presence of faecal coliforms (FC). Staphylococcus aureus could not be detected in $5(35.7 \%)$ samples tested. $50 \%$ of the samples were contaminated with Pseudomonas spp. 9 (64.3\%) samples were found to be contaminated with Listeria spp. Table 3 shows the presence of Salmonella, Shigella and Vibrio spp. following enrichment and selective culture as previously described. None of the samples showed the presence of Salmonella and Shigella spp. However, sample 3-CF-L and 10-CA-S showed the presence of Vibrio spp. Table 4 demonstrates the proportion of bacterial contamination as compared to the total number of isolates. Local market samples were mostly contaminated with E. coli $(4 / 7,57.1 \%)$ followed by Listeria spp. (3/7, $42.9 \%$ ) and Staphylococcus aureus (3/7, 42.9\%). Super market vegetables showed different pattern and were found to be contaminated with Pseudomonas spp. (5/7, $71.4 \%)$ and Listeria spp. (5/7, 71.4\%).

Antibiotic sensitivity patterns of the pathogenic bacteria isolated in this study from both local and super market samples are shown in Table 5. Resistance against Imipenem (25\%), Ceftriaxone (91.7\%), Sulfamethoxazole (58.3\%), Ampicillin (83.3\%) and Cefuroxime (83.3\%) were found to be higher in pathogens isolated from super shops than those of local market. Pathogenic bacteria isolated from local market vegetables showed higher level of resistance against other antibiotics such as, Gentamicin (38.5\%), Aztronam (53.8\%) and Oxacillin (33.3\%) compared to those isolated from super shop vegetables. 
TABLE 2. Bacterial load in vegetable sample collected from local and super shops.

\begin{tabular}{ccccccc}
\hline & \multicolumn{5}{c}{ Bacterial load (cfu/g) } \\
\cline { 2 - 6 } Sample ID & THB & TC & FC & Staphlococcus aureus & Pseudomonous spp. & Listeria spp. \\
\hline 1-T-L & $7.4 \times 10^{5}$ & $1.1 \times 10^{3}$ & 0 & 0 & 0 & 0 \\
2-T-S & $3.5 \times 10^{4}$ & $9.0 \times 10^{1}$ & 0 & 0 & $5.4 \times 10^{3}$ & 0 \\
3-CF-L & $4.8 \times 10^{5}$ & $1.2 \times 10^{3}$ & 0 & $2.8 \times 10^{3}$ & $5.4 \times 10^{4}$ & 0 \\
4-CF-S & $8.0 \times 10^{4}$ & $4.0 \times 10^{2}$ & 0 & $4.0 \times 10^{1}$ & 0 & $3.0 \times 10^{1}$ \\
5-CB-L & $3.2 \times 10^{5}$ & $5.0 \times 10^{2}$ & 0 & $8.0 \times 10^{2}$ & 0 & $1.6 \times 10^{3}$ \\
6-CB-S & $4.8 \times 10^{4}$ & 0 & 0 & 0 & $2.0 \times 10^{2}$ & $6.0 \times 10^{2}$ \\
7-B-L & $4.9 \times 10^{4}$ & 0 & 0 & $2.5 \times 10^{1}$ & $3.0 \times 10^{2}$ & $2.0 \times 10^{3}$ \\
8-B-S. & $3.7 \times 10^{4}$ & $8.0 \times 10^{2}$ & 0 & $2.3 \times 10^{1}$ & $4.0 \times 10^{2}$ & $2.0 \times 10^{2}$ \\
9-CA-L & $5.1 \times 10^{4}$ & $1.6 \times 10^{2}$ & 0 & $3.0 \times 10^{2}$ & $4.1 \times 10^{2}$ & $1.4 \times 10^{2}$ \\
10-CA-S & $3.5 \times 10^{4}$ & $8.0 \times 10^{2}$ & 0 & 0 & 0 & $2.0 \times 10^{2}$ \\
11-R-L & $5.8 \times 10^{5}$ & $1.2 \times 10^{3}$ & 0 & $1.6 \times 10^{3}$ & 0 & 0 \\
12-R-S & $4.0 \times 10^{4}$ & 0 & 0 & 0 & $8.0 \times 10^{2}$ & $3.0 \times 10^{2}$ \\
13-T-L & $5.2 \times 10^{5}$ & $1.0 \times 10^{2}$ & 0 & $2.2 \times 10^{3}$ & 0 & $1.4 \times 10^{1}$ \\
14-T-S & $3.9 \times 10^{5}$ & $2.0 \times 10^{1}$ & 0 & $3.0 \times 10^{2}$ & $7.2 \times 10^{2}$ & 0 \\
\hline
\end{tabular}

$\mathrm{THB}=$ Total heterotrophic bacteria $; \mathrm{TC}=$ Total coliform $; \mathrm{FC}=$ Faecal coliform

TABLE 3. Growth of Salmonella, Shigella and Vibrio spp. in vegetable samples

\begin{tabular}{ccc}
\hline $\begin{array}{c}\text { Sample } \\
\text { ID }\end{array}$ & $\begin{array}{c}\text { Salmonella } \text { and } \\
\text { Shigella spp. }\end{array}$ & Vibrio spp. \\
\hline 1-T-L & - & - \\
2-T-S & - & - \\
3-CF-L & - & + \\
4-CF-S & - & - \\
5-CB-L & - & - \\
6-CB-S & - & - \\
7-B-L & - & - \\
8-B-S. & - & - \\
9-CA-L & - & - \\
10-CA-S & - & + \\
11-R-L & - & - \\
12-R-S & - & - \\
13-T-L & - & - \\
14-T-S & - & - \\
\hline
\end{tabular}

- = Growth negative; $+=$ Growth positive

TABLE 4. Proportions of pathogenic bacteria isolated from local and super shops

\begin{tabular}{ccc}
\hline Organism & $\begin{array}{c}\text { Local market, } \mathrm{n} \\
(\%)\end{array}$ & $\begin{array}{c}\text { Super market, } \mathrm{n} \\
(\%)\end{array}$ \\
\hline Pseudomonas spp. & $2 / 7(28.6)$ & $5 / 7(71.4)$ \\
Vibrio spp. & $1 / 7(14.3)$ & $1 / 7(14.3)$ \\
Listeria spp. & $3 / 7(42.9)$ & $5 / 7(71.4)$ \\
Staphylococcus aureus & $3 / 7(42.9)$ & $1 / 7(14.3)$ \\
E. coli & $4 / 7(57.1)$ & $0 / 7(0)$ \\
Salmonella and Shigella spp. & $0 / 7(0)$ & $0 / 7(0)$ \\
\hline
\end{tabular}

\section{DISCUSSION}

Outbreaks of human diseases associated with the consumption of raw fruits and vegetables have been increasing in the developing as well as developed countries of the world during the past decade. In Bangladesh, vegetables are common food regularly consumed with major meals. Salad vegetables are often taken as raw without cooking as a side menu in lunch or dinner. Consequently, consumption of contaminated vegetable may set outbreak of food borne diseases and may put the overall public health at a serious risk. This could be linked to the fact that most of these vegetables are consumed without any thermal process or washing (16). The present study focuses on the determination of bacterial load and contamination of pathogenic bacteria in common vegetables sold by the two categories of shops in Dhaka city.

Microbial contamination of vegetables may result from various unsanitary practices during cultivation and marketing (17). These vegetables can become contaminated with pathogenic microorganisms during harvesting, through human handling and use of harvesting equipment, transport containers, wild and domestic animals. In another study it was reported that bacterial contamination of salad vegetables was linked to the fact that they are usually consumed raw without any heat treatment (18). Consequently, pathogens from human, animal and environmental sources could be detected in foods ready for consumption. Besides the spoilage bacteria, yeasts and mould on raw fruits and vegetable, pathogenic bacteria, parasites and viruses have also been reported (19).

Contamination of vegetables with coliform bacteria indicates the possible presence of other enteric pathogens which was very much apparent in this study. Faecal coliforms are thermo tolerant members of coliform group which indicate contamination of vegetables from faecal matter. Although E. coli is considered as the normal flora of the human intestines, some strains of $E$. coli have been linked to diarrhoea, gastro-enteritis and urinary tract infections (19). Escherichia coli and Klebsiella spp. are well known coliform bacteria that are frequently isolated from soil, water in the environment (20). Escherichia coli, Klebsiella spp. and Enterobacter spp. were also isolated from vegetables by other workers (17). In a previous study E. coli was found to be predominant in some salad vegetables which included coriander, carrot, radish, spinach, fenugreek and cucumber (18). This study showed that coliforms, E. coli, S. aureus, Vibrio spp. and 
TABLE 5. Antibiotic sensitivity patterns of bacteria isolated from vegetables collected from local and super shops

\begin{tabular}{|c|c|c|c|c|c|c|c|c|c|}
\hline Sample ID & Organism & IPM-10 & CRO-30 & SXT-25 & AMP-10 & $\mathrm{CN}-10$ & ATM-30 & CXM-30 & OX-5 \\
\hline 3-CF-L & Vibrio spp. & I & $\mathrm{R}$ & $\mathrm{R}$ & $\mathrm{S}$ & $\mathrm{S}$ & $\mathrm{R}$ & I & ND \\
\hline 3-CF-L & Pseudomonas spp. & $\mathrm{S}$ & $\mathrm{R}$ & $\mathrm{S}$ & I & $\mathrm{S}$ & $\mathrm{S}$ & $\mathrm{R}$ & ND \\
\hline 5-CB-L & S. aureus & $\mathrm{S}$ & $\mathrm{S}$ & $\mathrm{S}$ & $\mathrm{S}$ & $\mathrm{S}$ & $\mathrm{R}$ & $\mathrm{S}$ & $\mathrm{S}$ \\
\hline 5-CB-L & Listeria spp. & $\mathrm{R}$ & $\mathrm{S}$ & $\mathrm{S}$ & $\mathrm{R}$ & $\mathrm{S}$ & $\mathrm{S}$ & I & ND \\
\hline 5-CB-L & E. coli & $\mathrm{S}$ & I & $\mathrm{S}$ & $\mathrm{R}$ & $\mathrm{S}$ & $\mathrm{S}$ & I & ND \\
\hline 7-B-L & Pseudomonas spp. & I & $\mathrm{R}$ & $\mathrm{R}$ & $\mathrm{S}$ & $\mathrm{R}$ & $\mathrm{R}$ & $\mathrm{R}$ & ND \\
\hline 7-B-L & Listeria spp. & $\mathrm{S}$ & I & $\mathrm{S}$ & $\mathrm{R}$ & $\mathrm{R}$ & $\mathrm{R}$ & $\mathrm{R}$ & ND \\
\hline 9-CA-L & E. coli & I & I & I & $\mathrm{R}$ & $\mathrm{S}$ & $\mathrm{S}$ & $\mathrm{R}$ & ND \\
\hline 9-CA-L & Listeria spp. & I & I & $\mathrm{S}$ & $\mathrm{R}$ & $\mathrm{R}$ & $\mathrm{R}$ & $\mathrm{R}$ & ND \\
\hline 11-R-L & S. aureus & $\mathrm{S}$ & $\mathrm{R}$ & $\mathrm{S}$ & $\mathrm{R}$ & $\mathrm{S}$ & $\mathrm{R}$ & I & $\mathrm{S}$ \\
\hline 11-R-L & E. coli & I & $\mathrm{S}$ & I & $\mathrm{R}$ & $\mathrm{R}$ & I & $\mathrm{R}$ & ND \\
\hline 13-T-L & S. aureus & $\mathrm{S}$ & $\mathrm{R}$ & $\mathrm{S}$ & $\mathrm{S}$ & $\mathrm{S}$ & $\mathrm{R}$ & $\mathrm{R}$ & $\mathrm{R}$ \\
\hline 13-T-L & E. coli & $\mathrm{R}$ & $\mathrm{R}$ & $\mathrm{S}$ & $\mathrm{R}$ & $\mathrm{R}$ & $\mathrm{S}$ & $\mathrm{R}$ & ND \\
\hline $\begin{array}{c}\text { Local } \\
\text { market }\end{array}$ & $\begin{array}{c}\text { Total resistance } \\
(\%)\end{array}$ & $\begin{array}{c}2 / 13 \\
(15.4)\end{array}$ & $\begin{array}{c}6 / 13 \\
(46.2)\end{array}$ & $\begin{array}{c}2 / 13 \\
(15.4)\end{array}$ & $\begin{array}{c}8 / 13 \\
(61.5)\end{array}$ & $\begin{array}{c}5 / 13 \\
(38.5)\end{array}$ & $\begin{array}{c}7 / 13 \\
(53.8)\end{array}$ & $\begin{array}{c}8 / 13 \\
(61.5)\end{array}$ & $\begin{array}{c}1 / 3 \\
(33.3)\end{array}$ \\
\hline $2-\mathrm{T}-\mathrm{S}$ & Pseudomonas spp. & $\mathrm{S}$ & $\mathrm{R}$ & I & $\mathrm{R}$ & $\mathrm{S}$ & I & $\mathrm{R}$ & ND \\
\hline 4-CF-S & Listeria spp. & S & $\mathrm{R}$ & $\mathrm{R}$ & $\mathrm{R}$ & $\mathrm{S}$ & $\mathrm{R}$ & $\mathrm{R}$ & ND \\
\hline 4-CF-S & $\begin{array}{c}\text { Staphylococcus } \\
\text { aureus }\end{array}$ & $\mathrm{S}$ & $\mathrm{R}$ & $\mathrm{R}$ & $\mathrm{S}$ & $\mathrm{S}$ & $\mathrm{R}$ & I & S \\
\hline $6-\mathrm{CB}-\mathrm{S}$ & Pseudomonas spp. & $\mathrm{S}$ & $\mathrm{R}$ & $\mathrm{R}$ & $\mathrm{R}$ & I & $\mathrm{S}$ & $\mathrm{R}$ & ND \\
\hline 6-CB-S & Listeria spp. & $\mathrm{R}$ & $\mathrm{R}$ & $\mathrm{R}$ & $\mathrm{R}$ & $\mathrm{S}$ & $\mathrm{R}$ & $\mathrm{R}$ & ND \\
\hline 8-B-S & Pseudomonas spp. & $\mathrm{S}$ & $\mathrm{R}$ & $\mathrm{R}$ & $\mathrm{R}$ & $\mathrm{S}$ & $\mathrm{R}$ & $\mathrm{R}$ & ND \\
\hline $8-B-S$ & Listeria spp. & $\mathrm{R}$ & I & $\mathrm{S}$ & $\mathrm{R}$ & $\mathrm{S}$ & $\mathrm{S}$ & $\mathrm{R}$ & ND \\
\hline 10-CA-S & Vibrio spp. & $\mathrm{S}$ & $\mathrm{R}$ & $\mathrm{R}$ & $\mathrm{S}$ & $\mathrm{S}$ & $\mathrm{R}$ & $\mathrm{R}$ & ND \\
\hline 10-CA-S & Listeria spp. & $\mathrm{S}$ & $\mathrm{R}$ & $\mathrm{S}$ & $\mathrm{R}$ & $\mathrm{R}$ & $\mathrm{S}$ & $\mathrm{R}$ & ND \\
\hline $12-\mathrm{R}-\mathrm{S}$ & Pseudomonas spp. & $\mathrm{S}$ & $\mathrm{R}$ & I & $\mathrm{R}$ & $\mathrm{S}$ & I & $\mathrm{R}$ & ND \\
\hline $12-\mathrm{R}-\mathrm{S}$ & Listeria spp. & $\mathrm{R}$ & $\mathrm{R}$ & $\mathrm{S}$ & $\mathrm{R}$ & $\mathrm{S}$ & $\mathrm{S}$ & I & ND \\
\hline $14-\mathrm{T}-\mathrm{S}$ & Pseudomonas spp. & $\mathrm{S}$ & $\mathrm{R}$ & $\mathrm{R}$ & $\mathrm{R}$ & $\mathrm{S}$ & $\mathrm{R}$ & $\mathrm{R}$ & ND \\
\hline $\begin{array}{c}\text { Super } \\
\text { market }\end{array}$ & $\begin{array}{c}\text { Total resistance } \\
(\%)\end{array}$ & $\begin{array}{c}3 / 12 \\
(25.0)\end{array}$ & $\begin{array}{l}11 / 12 \\
(91.7)\end{array}$ & $\begin{array}{c}7 / 12 \\
(58.3)\end{array}$ & $\begin{array}{c}10 / 12 \\
(83.33)\end{array}$ & $\begin{array}{l}1 / 12 \\
(8.3)\end{array}$ & $\begin{array}{c}6 / 12 \\
(50.0)\end{array}$ & $\begin{array}{l}10 / 12 \\
(83.3)\end{array}$ & $\begin{array}{c}0 / 1 \\
(0.0)\end{array}$ \\
\hline
\end{tabular}

IPM-10 = Imipenm $(10 \mu \mathrm{g}) ;$ CRO30 = Ceftriaxone $(30 \mu \mathrm{g}) ;$ SXT-25 = Sulfamethoxazole, $25 \mu \mathrm{g} ;$ AMP-10 = Ampicillin $(10 \mu \mathrm{g}) ; \mathrm{CN}-10=$ Gentamicin $(10 \mu \mathrm{g})$; ATM-30 = Aztronam $(30 \mu \mathrm{g})$; CXM-30 = Cefuroxime $(30 \mu \mathrm{g})$; OX-5 = Oxacillin $(5 \mu \mathrm{g})$; ND = Not Done; R = Resistant; $\mathrm{S}=$ Sensitive; I = Intermediate.

Pseudomonas spp. were common in vegetable samples which are concordant with previous study results (21).

Staphylococcal contaminations have been linked to carriage in nasal cavities of food handlers or by infected workers. Such contamination can be a serious threat to public health because of the ability of the pathogen to cause food-borne infections and food-borne intoxication (18). Salad vegetables such as carrots, cucumber, tomato and radishes have also been reported to be contaminated with Gram negative bacteria (1).

Fresh fruits and vegetables can be contaminated with waterborne pathogens such as, Salmonella spp., Shigella spp. and Vibrio spp. if they are treated with contaminated water. In this study, Salmonella spp. and Shigella spp. could not be isolated from the vegetable samples but two samples showed the contamination of Vibrio spp. According to the WHO (2002), contamination of food items with notable pathogens like Salmonella spp. and Vibrio spp. is now a major public health concern worldwide (22). Salmonella spp. has also been isolated from carrots, cucumber and lettuce collected from different markets and vendors in Nigeria and other parts of the world $(20,23)$.

The sanitary quality of the cultivation water, harvesting, transportation, storage, and processing of the produce will directly influence the load and types of microorganisms in fresh vegetables (1). Bacterial contamination of fruits and vegetables has also been reported by other workers in a separate study conducted in India (18). Growth and survival of microorganisms in vegetables will depend on the availability of nutrients and inhibitors present on their intact their intact and bruised skins (24). Often microorganisms can gain entry through the stomata, lenticels, broken trichomes and stem scars and may survive (25).

Prevalence of pathogenic bacteria in supermarket samples slightly varied from that of local market. The proportions of Pseudomonas spp. (71.4\%) and Listeria spp. (71.4\%) were relatively higher in the super shop samples compared to those of local shops. On the contrary, proportions of Staphylococcus aureus (14.3\%) and $E$. coli $(0 \%)$ were found to be lower in supermarket samples. These results indicate the better management of vegetables in supermarkets in relatively better handling and preservation of vegetables in chillers possibly helped to reduce the contamination of $S$. aureus and E. coli. However, survival ability of Listeria spp. and Pseudomonas spp. at refrigeration temperature could be 
responsible for the increased concentration of these pathogens. Sometimes resistant bacteria such as, Pseudomonas spp. can survive in disinfectant solutions and build up their concentration in those solutions. Repeated use of these contaminated sanitizers might have helped increase the proportion of resistant bacteria in supermarket samples.

Overall, this study revealed the presence of a high load of microorganisms in the commonly consumed vegetables items in both local market and super shop among in Dhaka city. All samples from both the categories showed THB which ranged between $3.5 \times 10^{4}$ and $7.4 \times 10^{5} \mathrm{cfu} / \mathrm{g}$, Although total coliforms could be detected in 11/14 (78.6\%) samples, none of the samples showed the presence of faecal coliforms in this study. This result indicates that the contaminating bacteria were introduced to the vegetable samples from an environmental source and not from any faecal source. Future study could be done for tracking the source of contamination present in the environment. Pathogenic bacteria might be introduced from the cultivation land, organic fertilizers, irrigating water, packaging materials and transport vehicles.

It is important to determine the antibiotic resistance patterns of the pathogenic bacteria for appropriate treatment of infectious disease. Increase in the resistance pattern will complicate the treatment options and increase the cost of treatment and patient management. In this study, pathogenic bacteria isolated from the supermarket showed higher level of resistance against most of the common antibiotics tested compared to those of local market. It will be necessary to investigate the causes of this increased resistance in pathogens isolated form supermarkets. Frequent application of disinfectants and related chemicals used for sanitation and cleaning may be related to the increase in the antibiotic resistance amongst pathogenic bacteria. Increased antibiotic resistance amongst the pathogens isolated from super market vegetables is a great concern for the consumers and the society. Contaminating pathogens are capable of causing various types of enteric diseases as well as serious intoxications in human health. Further studies need to be done for detection of the virulent genes in the pathogenic bacteria for predicting and determining the cause of outbreak of diseases. It is also necessary to create awareness among the producers, processors, handlers and consumers of raw vegetables through campaign and related social activities. Such activities will help reduce the bacterial contamination and risk of illness associated with the consumption of contaminated vegetables. Improvement in the health and hygiene condition during vegetable production, handling, storage and distribution will be necessary to control foodborne diseases due to the consumption of contaminated vegetables.

\section{CONCLUSION}

In this study microbial load in vegetable samples collected from the local and super shops demonstrated high load of THB, TC, S. aureus, Pseudomonas spp. and Listeria spp. Only 2 out of 14 samples showed the presence of Vibrio spp. Antibiotic resistance pattern was higher amongst the pathogens isolated form super shop samples. This is a matter of concern for the new types of shops under operation in Dhaka, Bangladesh. Necessary steps should be taken to reduce the level of contamination in vegetables sold either in local or super shops. It will be also necessary to create awareness among the vegetable producer, businessman and general public to significantly reduce the propagation and spread of antibiotic resistance bacteria. A larger scale study will be necessary to determine the sources of pathogenic bacteria and antibiotic resistant trait and to suggest necessary steps to be taken for appropriate intervention.

\section{REFERENCES}

1. Beuchat, C. R. 1995. Pathogenic microorganisms associated with fresh produces. J. Food Protec. 59: 204-216.

2. Soriano, J. M., H. Rico, J. C. Molto, and J. Ma. 2001. Incidence of microbial flora in lettuce, meat and Spanish potato omelette from restaurant. Food Microbiol. 18: 159-163.

3. Amoah, P., P. Drechsel, R. C. Abidoo, and E. M. Abraham. 2009 Improving food hygiene in Africa where vegetables are irrigated with polluted water. Regional Sanitation and Hygiene Symposium, Accra, Ghana.

4. Zhao, T., M. R. S. Clavero, M. P. Doyle, and L. R. Beuchat. 1997. Health relevance of the presence of fecal coliforms in iced tea and in leaf tea. J. Food Protec. 60: 215-218.

5. Centre for Disease Control and Prevention (CDC). 2000. Surveillance for foodborne-disease outbreaks-United States, 1993-1997. Morb. Mortal. Wkly. Rep. 49 (SS01): 1-51.

6. Cray, W. C. J., and W. H. Moon. 1995. Experimental infection of calves and adult cattle with Escherichia coli O157:H7. Appl. Environ. Microbiol. 61 (4): 1586-1590.

7. Snowdon, J. A., D. O. Cliver, and J. C. Converse. 1989. Land disposal of mixed human and animal wastes: A review. Waste Manag. Res. 7: 121-134.

8. Starutch, D. 1991. Survival of pathogenic microorganisms and parasites in excreta, manure sand sewage sludge. Rev. Sci. Tech. Off. Int. Epiz. 10 (3): 813-846.

9. Sahilah, A. M., et al. 2010. Detection of virulence genes and enterobacterial repetitive intergenic consensus-PCR (ERIC-PCR) analysis among raw vegetables isolates of Campylobacter jejuni. Int. Food Res. J. 17: 681- 690.

10. Fremaux, B., et al. 2007. Growth and Survival of non-O157: H7 shigatoxinproducing E. coli in cow manure. J. Appl. Microbiol. 102: 89-99.

11. Piechulek, H., A. Al-Sabbir, and J. Mendoza-Aldana. 2003. Diarrhoea and ARI in rural areas of Bangladesh. Southeast Asian J. Trop. Med. Public Health. 34 (2): 337-42.

12. American Public Health Association (APHA). 2012. Standard Methods for the Examination of Water \& Wastewater, 22 ${ }^{\text {nd }}$ ed. American Water Works Association (AWWA) \& Water Environment Federation (WEF).

13. Cappuccino, J. G., and N. Sherman. 1996. Microbiology- A laboratory manual, $4^{\text {th }}$ ed. The Benjamin/Cummings Publishing Co., Inc., Menlo Park, California.

14. Alfrad, E. B. 2007. Bensons microbiological applications. Mcgraw-Hill Book Company, New York.

15. Clinical and Laboratory Standards Institute (CLSI). 2011. Performance Standards for antimicrobial susceptibility testing; Twenty-first informational supplement. CLSI document M100-S21 (ISBN 1-56238-742-1), Clinical and Laboratory Standards Institute, 940 West Valley Road, Suite 1400, Wayne, Pennsylvania 19087 USA. 
16. Lund, B. M. 1992. Ecosystems in vegetable foods. J. Appl. Bacteriol. 73 : $115-135$.

17. Khan, M. R., M. L. Saha, and A. M. Kibria. 1992. A bacteriological profile of salad vegetables in Bangladesh with special reference to coliforms. Appl. Microbiol. 14: 88-90.

18. Tambekar, D. H., and R. H. Mundhada. 2006. Bacteriological quality of salad vegetables sold in Amravati city, India. J. Biolog. Sci. 6: 28-30.

19. Hasan, A., O. Utku, and K. Koray. 2006. Determination of total aerobic and indicator bacteria on some raw eaten vegetables from wholesalers in Ankara, Turkey. International J. Hyg. Environ. Health. 209: 197-201.

20. Ibrahim, S. A. 1996. Microbiological studies on some salad vegetable in local markets. J. King Saud Univer. 8: 99-106.

21. Rahman, F., and R. Noor. 2012. Prevalence of pathogenic bacteria in common salad vegetables of Dhaka metropilis. Bang. J. Bot. 41 (2): 159162.
22. World Health Organization (WHO) \& Food and Agriculture Organization of the United Nations. 2002. Risk assessments of Salmonella in eggs and broiler chickens. Microbiological Risk Assessment Series 2, WHO \& FAO

23. Itohan, A. M., O. Peters, and I. Kolo. 2011. Bacterial contaminants of salad vegetables in Abuja Municipal Area Council, Nigeria. Malays. J. Microbiol. 7 (2): 111-114.

24. Odhav, B., S. Beekrum, U. Akula, and H. Baijnath. 2007. Preliminary assessment of nutritional value of traditional leafy vegetables in KwaZuluNatal, South Africa. J. Food Comp. Ana. 20: 430-435.

25. Bartz, J. A., and C. I. Wei. 2003. The influence of bacteria postharvest physiology and pathology of vegetables, $2^{\text {nd }}$ ed. Marcel Dekker, Inc, New York. 